\title{
Review Article \\ D-Lactic Acid as a Metabolite: Toxicology, Diagnosis, and Detection
}

\author{
Miroslav Pohanka \\ Faculty of Military Health Sciences, University of Defense, Trebesska 1575, Hradec Kralove CZ-50001, Czech Republic \\ Correspondence should be addressed to Miroslav Pohanka; miroslav.pohanka@gmail.com
}

Received 5 March 2020; Revised 20 May 2020; Accepted 6 June 2020; Published 18 June 2020

Academic Editor: Maxim P. Evstigneev

Copyright ( 2020 Miroslav Pohanka. This is an open access article distributed under the Creative Commons Attribution License, which permits unrestricted use, distribution, and reproduction in any medium, provided the original work is properly cited.

\begin{abstract}
Two enantiomers of lactic acid exist. While L-lactic acid is a common compound of human metabolism, D-lactic acid is produced by some strains of microorganism or by some less relevant metabolic pathways. While L-lactic acid is an endogenous compound, D-lactic acid is a harmful enantiomer. Exposure to D-lactic acid can happen by various ways including contaminated food and beverages and by microbiota during some pathological states like short bowel syndrome. The exposure to D-lactic acid cannot be diagnosed because the common analytical methods are not suitable for distinguishing between the two enantiomers. In this review, pathways for D-lactic acid, pathological processes, and diagnostical and analytical methods are introduced followed by figures and tables. The current literature is summarized and discussed.
\end{abstract}

\section{Introduction}

Toxicity of optical isomers is a specific issue that is not easy to be studied. When a compound is existing in a form of optical isomer (enantiomer), frequently one isomer is harmless or even necessary for homeostasis (e.g., L-amino acids) while the other isomer is toxic and able to interfere crucial pathways in the organism. On the other hand, some isomers do not exert significant problems (e.g., sugars). The toxicity depending on chirality is known from natural toxins, drugs, and pesticides [1-5]. Production of enantiopure drugs is a specific issue where high demands on quality of manufacturing and control are given. The manufacturing processes should be able to prefer or be fully selective to only one isomer. It can be reached by biocatalysis [6], advanced organic synthesis [7], and enantiospecific separation [8].

Though an unequal biological effect of optical isomers is known for a relatively long time, it is frequently underestimated because elaborative and expensive laboratory tests are necessary to distinguish the isomers. This review is focused on D-lactic acid which is, comparing to its Lisomer counterpart, problematic for the humans, and excessive intake can have fatal consequences. A survey of the actual literature, discussion of known facts, and ongoing research are provided in this work.

\section{Comparison of the D- and L-Lactic Acids}

Lactic acid exists in the form of two enantiomers: D-lactic acid and L-lactic acid. In proper chemical terms, the Llactic acid should be entitled L(+) lactic acid or $\mathrm{S}(+)$ lactic acid while the $\mathrm{D}$ variant is named $\mathrm{D}(-)$ lactic acid respective $\mathrm{R}(-)$ lactic acid. The isomers are depicted in Figure 1.

Lactic acid exists as a conjugated base lactate (L-lactate in the case of L-lactic acid and D-lactate in the case of D-lactic acid) in physiological pH 7.4, but the occurrence of conjugated base has no effect on chirality that is kept in the basic anion. L-Lactic acid is the natural enantiomer in humans and other higher forms of life. A normal level of L-lactate in human blood is in a range from 0.5 to $1 \mathrm{mmol} / \mathrm{l}$, the increased level above the normal physiological range is called hyperlactatemia, and it can be initiated by some pathological processes. The low level of L-lactate is entitled as hypolactatemia [9]; however, hypolactatemia is quite a rare phenomenon comparing to indication of pathological states by hyperlactatemia which is a relevant finding in clinical 


$$
\mathrm{HO} \underset{\underset{\mathrm{CH}}{\mathrm{C}} \mathrm{H}}{\mathrm{COOH}}
$$$$
\mathrm{H} \underset{\mathrm{CH}_{3}}{\stackrel{\mathrm{COOH}}{+} \mathrm{OH}}
$$

$\mathrm{L}(+)$ lactic acid

$\mathrm{D}(-)$ lactic acid

Figure 1: D- and L-lactic acids.

biochemistry. Lactic acidosis occurs when the L-lactate concentration exceeds $4 \mathrm{mmol} / \mathrm{l}$ in plasma, and blood $\mathrm{pH}$ can drop under 7.35 in this situation. Hyperlactatemia in a mild form or a form of lactic acidosis can appear from several reasons like sepsis, hemorrhagic shock, cardiac arrest, trauma, poisonings, ischemia, burns, diabetic ketoacidosis, some types of cancer, and intense muscle activity [10-18].

Standard metabolism of L-lactate in most organisms is mediated by L-lactate dehydrogenase (EC 1.1.1.27) in the presence of $\mathrm{NAD}^{+}$as a cofactor. The reaction is in its principle the same like the oxidation of D-lactate by D-lactate dehydrogenase (EC 1.1.1.28). The enzyme is quite evolutionary conserved because it can be found in eukaryotes, bacteria, and even archaea. Pyruvate and NADH are products of the reaction. The principle of L-lactate oxidation to pyruvate by L-lactate dehydrogenase is shown in Figure 2. The L-lactate dehydrogenase is involved in a basic metabolism tightly linked to glycolysis and gluconeogenesis, and it is a crucial part of the Cori cycle in humans and higher animals, but it also participates in fermentation processes [19-23].

Comparing to L-lactic acid, the D-lactic acid is not involved in basic metabolic processes of most life forms. Enzymes responsible for lactate metabolism including Llactate dehydrogenase exert specificity to the L-isomer only, and they are not able to convert D-lactic acid. Only some exceptional L-lactate dehydrogenases like the enzyme from Leuconostoc mesenteroides are able to be involved in D-lactate conversion besides standard metabolism of L-lactate [24].

\section{Basic Biochemical Pathways for D-Lactic Acid}

Various bacterial species are able to produce D-lactate or both D- and L-lactates contemporarily. Many of them are involved in fermentation processes including the processes known from biotechnology industry. The genus of bacteria Lactobacillus produces D, L, and racemic mixture, genus Pediococcus produces either pure $\mathrm{L}$ or some strain racemic mixture, Leuconostoc and Oenococcus are producers of D-isomer, and genus Weissella produces either $\mathrm{D}$-isomer or racemic mixture [25]. Engineered strains of bacteria can serve for optical isomer production. Aso and coworkers described $\mathrm{Lac}$ tococcus lactis-based biotechnology for D-lactic acid production [26].

There are more pathways on how D-lactate is produced by microorganisms, fungi, and others. D-Lactate dehydrogenase (EC 1.1.1.28) is one of them. Fungi Phytophthora undulata, Pythium debaryanum, and Sapromyces elongatus [27] and bacteria Lactobacillus delbrueckii [28], Lactobacillus bulgaricus [29], Escherichia coli, Fusobacterium nucleatum, and Pseudomonas aeruginosa [30] are organisms known for expression of D-lactate dehydrogenase. D-Lactate dehydrogenase is an enzyme that converts D-lactate to pyruvate by contemporary reduction of $\mathrm{NAD}^{+}$to $\mathrm{NADH}$.

D-Lactate dehydrogenase (cytochrome) is another enzyme converting D-lactate. It is an enzyme known under code EC 1.1.2.4. It consumes D-lactate and needs two molecules of ferricytochrome c, while pyruvate and two molecules of ferrocytochrome $c$ are reaction products. Activity of this enzyme was described for instance in plant Arabidopsis thaliana [31], yeast Hansenula polymorpha [32], and yeast Saccharomyces cerevisiae [33]. Participation of D-lactate dehydrogenase (cytochrome) in human metabolism has not been extensively researched. In a study, activity of the enzyme in human mitochondria and its deletion in individuals with deficient enzyme was described and the relation with appearance of D-lactate in urine of the individuals with deficient enzyme was discussed [34].

D-Lactate dehydrogenase (cytochrome c-553) is an enzyme similar to the D-lactate dehydrogenase (cytochrome) or probably in some cases the same biological structure. It is an enzyme oxidizing D-lactate to pyruvate with contemporary reduction of two molecules of ferricytochrome c-553 to two molecules of ferrocytochrome c-553 in a single step. This enzyme was described in bacterium Desulfovibrio vulgaris [35]. Detailed information about the enzyme are not reported in the current literature.

Glyoxalase 3 is an enzyme accepting D-lactate as a substrate and involved in its detoxification. The enzyme is also known under the name D-lactate dehydratase and code EC 4.2.1.130. It catalyzes reaction where D-lactate produces methylglyoxal (2-oxopropanal) and one molecule of water. This enzyme was identified in humans [36]. Glyoxalases 1 and 2 are enzymes involved in D-lactate conversion respective production in humans as well $[37,38]$. Just as the system of glyoxalases makes a link between D-lactate and methylglyoxal, the methylglyoxal is further involved in forming advanced glycation end products, and in a wider look, it has a role in oxidative stress neurodegenerative disorders [39-42]. Enzymes involved in the lactate metabolism are summarized in Table 1.

\section{Poisoning by D-Lactate and D-Lactic Acidosis}

Production of lactic acids is common in biotechnologies of food processing, and manufacturing some types of food and beverages is typically based on or involves lactic acid production. Processes based on so-called lactic acid bacteria can be exampled [43]. Milk and milk beverage production can be complicated by D-lactic acid contamination depending on the type of bacterial presence [44]. There is a questionable effect of probiotics on the elevated level of D-lactate in blood circulation. Though some works point out potential risks of probiotics, the others show no evidence of increased Dlactate due to the probiotics and the final conclusion has not been done yet [45-48]. Moreover, production of Dlactate by probiotics is not related to all strains and use of D-lactic acid-producing strains is regulated, especially in products for children [25, 49]. In other experiments, the 


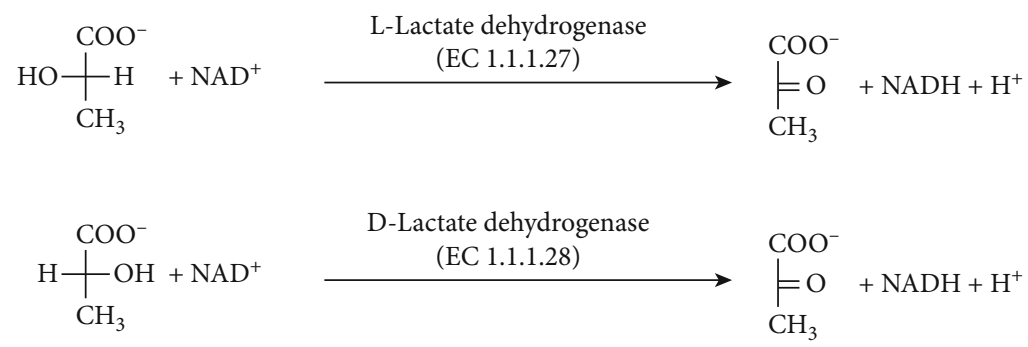

Figure 2: Oxidation of L-lactate by L-lactate dehydrogenase and D-lactate by D-lactate dehydrogenase to pyruvate.

TABLE 1: Enzymes involved in D-lactate metabolism.

\begin{tabular}{|c|c|c|c|c|c|}
\hline Name of enzyme & $\begin{array}{c}\text { EC } \\
\text { number }\end{array}$ & Substrates & Products & Producing organisms & References \\
\hline $\begin{array}{l}\text { D-Lactate } \\
\text { dehydrogenase }\end{array}$ & $\begin{array}{c}\mathrm{EC} \\
1.1 .1 .28\end{array}$ & D-Lactate $+\mathrm{NAD}^{+}$ & Pyruvate + NADH & $\begin{array}{c}\text { Fungi Phytophthora undulata, Pythium } \\
\text { debaryanum, and Sapromyces elongatus, bacteria } \\
\text { Lactobacillus delbrueckii, Lactobacillus bulgaricus, } \\
\text { Escherichia coli, Fusobacterium nucleatum, and } \\
\text { Pseudomonas aeruginosa }\end{array}$ & {$[27-30]$} \\
\hline $\begin{array}{l}\text { D-Lactate } \\
\text { dehydrogenase } \\
\text { (cytochrome) }\end{array}$ & $\begin{array}{c}\text { EC } \\
1.1 .2 .4\end{array}$ & $\begin{array}{c}\text { D-Lactate }+2 \\
\text { ferricytochrome c }\end{array}$ & $\begin{array}{c}\text { Pyruvate }+2 \\
\text { ferrocytochrome } \\
\mathrm{c}+2 \mathrm{H}^{+}\end{array}$ & $\begin{array}{c}\text { Plant Arabidopsis thaliana, yeast Hansenula } \\
\text { polymorpha and Saccharomyces cerevisiae }\end{array}$ & [31-33] \\
\hline $\begin{array}{l}\text { D-Lactate } \\
\text { dehydrogenase } \\
\text { (cytochrome c-553) }\end{array}$ & $\begin{array}{c}\text { EC } \\
1.1 .2 .5\end{array}$ & $\begin{array}{c}\text { D-Lactate }+2 \\
\text { ferricytochrome } \\
\text { c-553 }\end{array}$ & $\begin{array}{c}\text { Pyruvate }+2 \\
\text { ferrocytochrome } \\
c-553+2 \mathrm{H}^{+}\end{array}$ & Bacterium Desulfovibrio vulgaris & {$[35]$} \\
\hline $\begin{array}{l}\text { D-Lactate } \\
\text { dehydratase } \\
\text { (also glyoxalase } 3 \text { ) }\end{array}$ & $\begin{array}{c}\mathrm{EC} \\
4.2 .1 .130\end{array}$ & D-Lactate & Methylglyoxal $+\mathrm{H}_{2} \mathrm{O}$ & Homo sapiens & {$[36]$} \\
\hline
\end{tabular}

protective effect of probiotics was proven and their application was associated with reduction of D-lactate level [50].

Production of D-lactate by microbiota in the human organism is in limited amount under normal circumstances. D-Lactate can be overproduced by microbiota under specific circumstances like short bowel syndrome and jejunoileal bypass surgery further supported when a patient takes a meal with high sugar content $[51,52]$. Abdominal compartment syndrome, a multiorgan failure associated with fluid accumulation within the peritoneal and retroperitoneal spaces, is another risk factor for increased D-lactate concentration in blood [53]. The presence of D-lactate can follow poisoning to heavy metals despite the exact mechanism remaining unknown. It was precisely described in a model of Wistar rats exposed to lead [54]. Infectious diseases and diseases with following inflammation processes can also cause or be in relation with increased D-lactate level [55-58]. D-Lactate can also serve as a marker of some infections and sepsis [59]. D-Lactic acidosis is formed due to overproduction of D-lactate [60]. D-Lactic acid can be contained in food and beverages prepared by biotechnology processes or contaminated by microorganisms or the other way; e.g., beer can be contaminated by D-lactic acid [61-64].

D-Lactate initiates various pathological manifestations depending on the dose and individual conditions and specific metabolism. D-Lactate has a direct neurotoxic effect that is independent to the drop of blood $\mathrm{pH}$ and not common to L-lactate which was extensively scrutinized on Holstein calves as an experimental model [65]. In a case of Dlactate-poisoned lambs, acidosis, ataxic gait and preferred recumbency, and possible somnolence were identified and the symptoms can be suppressed by sodium bicarbonate [66]. Encephalopathy is also a common syndrome of Dlactate poisoning $[67,68]$. The neurotoxic effect of $\mathrm{D}$ lactate can be manifested by episodic confusion and hyperpnea as well [69]. Overall confusion, dizziness, headache, aggressive behavior, and memory loss are other symptoms following D-lactic acid poisoning [70]. An overview of types of D-lactic acid exposure and impact with manifestations is depicted in Figure 3. Though D-lactate can cause health complications, it is not a highly toxic compound because expected median lethal doses are quite high. The $\mathrm{LD}_{50}$ value level per orally poisoned rats is around $4.5 \mathrm{~g} / \mathrm{kg}$.

Because of environmental issues, good biocompatibility, and application in 3D printing, polylactic acid (synonym polylactide) becomes a highly preferred polymer that can be degraded in the nature [71-76]. The polylactic polymers in the current market are typically prepared from cheap racemic mixture of the D- and L-lactic acids, and it can be chemically named poly-DL-lactide. Use of optically pure isomers, from which poly-D-lactide and poly-L-lactide are formed, would make the final plastic products more expensive. On the other hand, the most commercially available lactic acid is the $\mathrm{L}$ enantiomer coming from the fermentation process, and the other significant source is a mixture fabricated chemically from acetaldehyde [77]. Hydrolysis of cellulose is possible 


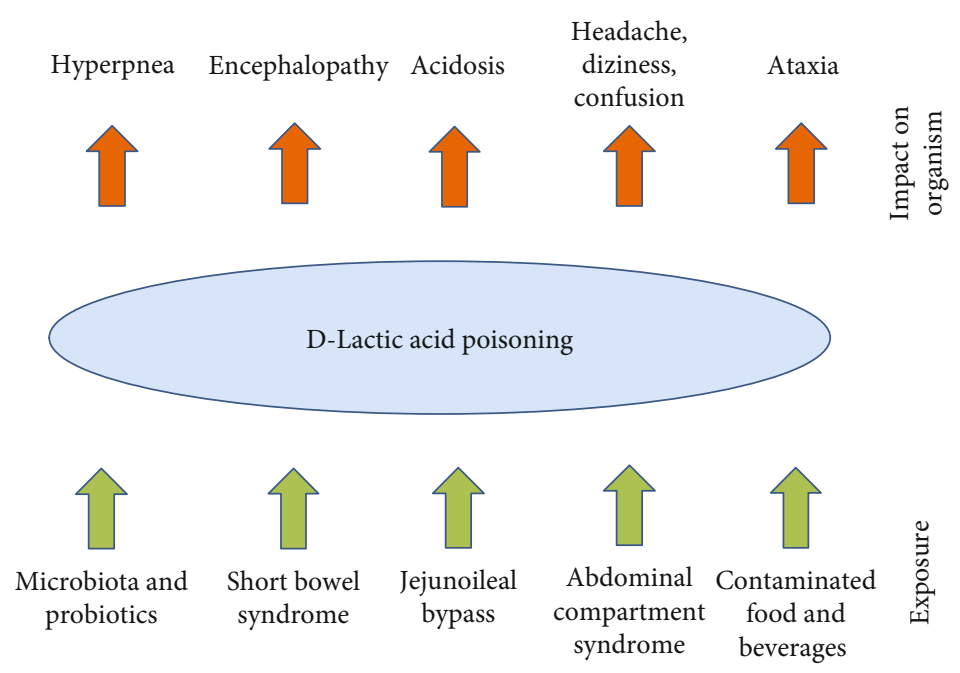

Figure 3: Overview of D-lactic acid exposures and impact on the organism.

as well $[78,79]$; there are also protocols for production of $\mathrm{D}$ lactate from methane [80]. Polylactic acid can be degraded by various processes, but hydrolysis of the ester bound is the most common reaction from the chemical point of view [81-83]; many organisms like bacterium Rhodopseudomonas palustris [84] and fungi Aspergillus niger and Candida cylindracea [85] are examples that have good ability to hydrolyze polylactic acid. Not a single enzyme is involved in polylactic acid hydrolysis. Lipases [85], carboxyl esterases [86], and serine proteases [87] were quoted as enzymes able to hydrolyze polylactic acid. Toxicity of polymers in the current market is generally low and hard to be measured. Some works however identified risks of the materials available in the current market, and the biodegradable materials like polylactic acid were surprisingly more harmful in the in vitro model [88]. Regarding polylactic acid, release of D-lactate due to metabolism should be taken into consideration; hence, products prepared from poly-DL-lactide and poly-D-lactide can be a certain risk when ingested.

\section{Diagnosis and Therapy}

Exposure to D-lactic acid can be diagnosed by standard biochemistry where some markers exert good dose-response relation. Besides this, the residual level of D-lactate in blood stream can be measured directly. The biochemical markers can point to a type of poisoning by an organic acid, but it is not easy to conclude that D-lactic acid is the causative agent of poisoning until further analytical tests are done. The exact assay of D-lactate in blood stream is not easy because Llactate and D-lactate have the same physical and chemical properties, and most analytical methods are not able to distinguish them. At the same time, L-lactate will interfere in an assay because physiological concentration in blood or blood plasma is quite high; its concentration can reach $2.5 \mathrm{mmol} / \mathrm{l}$, and it can even exceed $4 \mathrm{mmol} / \mathrm{l}$ under some conditions [89]. In the case of mild hyperlactatemia, L-lactate can reach $7 \mathrm{mmol} / \mathrm{l}$, and $12 \mathrm{mmol} / \mathrm{l}$ in a moderate case, and patients with severe hyperlactatemia can have a concentration above $12 \mathrm{mmol} / \mathrm{l}$ [90].

Standard biochemical markers can help in the diagnosis of D-lactic exposure and estimate the presence of D-lactate in blood stream. D-Lactic acid quantitatively produces Dlactate under physiological conditions which results in the drop of blood $\mathrm{pH}$ with possible occurrence of high anion gap and metabolic acidosis. The impact of $\mathrm{D}$-lactate on biochemical markers can be shown on a case of a 14-year-old boy that suffered from short bowel syndrome [69]. The patient had significantly higher concentration of D-lactate than L-lactate in blood plasma. While L-lactate was presented in a concentration of $2.89 \mathrm{mmol} / \mathrm{l}$, D-lactate reached $11.2 \mathrm{mmol} / \mathrm{l}$ at the same time. Base excess was equal to $-19.1 \mathrm{mmol} / \mathrm{l}$, anionic gap to $28.2 \mathrm{mmol} / \mathrm{l}$, and blood $\mathrm{pH}$ dropping to 7.23. In another described short bowel syndrome case, D-lactate reached a concentration of $8.9 \mathrm{mmol} / \mathrm{l}$ in blood while L-lactate was equal to $1.4 \mathrm{mmol} / \mathrm{l}$ and $\mathrm{pH}$ dropped to 7.30 with concurrent base excess of $-11.8 \mathrm{mmol} / \mathrm{l}$ in a nine-year-old boy [91]. A five-year-old girl with short bowel syndrome was described in a case report [92]. During hospitalization, she had the following values for blood serum: $\mathrm{pH} 7.16$, bicarbonate $5.2 \mathrm{mmol} / \mathrm{l}$, base excess $-20.2 \mathrm{mmol} / \mathrm{l}, \mathrm{L}-$ lactate $0.92 \mathrm{mmol} / \mathrm{l}$, and D-lactate $8.19 \mathrm{mmol} / \mathrm{l}$. In all the three previous case reports, relapses happened and acidosis appeared again despite medical supervision. A survey of biochemical parameters from the introduced case reports is given in Table 2.

The biochemical markers can be of course influenced by other pathologies as presented in the case report by Heireman and coworkers for a patient contemporarily suffering from urosepsis, uncontrolled type 2 diabetes mellitus, paracetamol overdosing, and gastric bypass surgery [93]. This combination led to impaired renal function, lowered consciousness, hyperventilation, diarrhea, vomiting, and development of high anion gap metabolic acidosis. Acidosis and the change of other biochemical markers can be initiated by other chemical substances in a similar way as described here for D-lactic acid. Ethylene glycol and methanol can be 
TABLE 2: Biochemical parameters of blood in D-lactate exposure case reports.

\begin{tabular}{lccccc}
\hline Patient & D-Lactate level & L-Lactate level & $\mathrm{pH}$ & Base excess & References \\
\hline 14-year-old boy suffering from short bowel syndrome & $11.2 \mathrm{mmol} / \mathrm{l}$ & $2.89 \mathrm{mmol} / \mathrm{l}$ & 7.23 & $-19.1 \mathrm{mmol} / \mathrm{l}$ & {$[69]$} \\
9-year-old boy suffering from short bowel syndrome & $8.9 \mathrm{mmol} / \mathrm{l}$ & $1.4 \mathrm{mmol} / \mathrm{l}$ & 7.30 & $-11.8 \mathrm{mmol} / \mathrm{l}$ & {$[91]$} \\
5-year-old girl suffering from short bowel syndrome & $8.19 \mathrm{mmol} / \mathrm{l}$ & $0.92 \mathrm{mmol} / \mathrm{l}$ & 7.16 & $-20.2 \mathrm{mmol} / \mathrm{l}$ & {$[92]$} \\
\hline
\end{tabular}

TABLE 3: Biochemical parameters of blood in D-lactate exposure case reports.

\begin{tabular}{lcc}
\hline Assay type & Principle of selectivity to D-isomer over L-isomer & References \\
\hline $\begin{array}{l}\text { Electrochemical biosensor } \\
\text { Electrochemical (amperometric) biosensor }\end{array}$ & Selectivity given by enzyme D-lactate dehydrogenase \\
$\begin{array}{l}\text { Optical (fluorimetry) test based on reduction } \\
\text { of NAD }{ }^{+} \text {to NADH }\end{array}$ & Selectivity given by enzyme D-lactate oxidoreductase (cytochrome) \\
GC MS & Delivity given by enzyme D-lactate dehydrogenase \\
Ultraperformance liquid chromatography-MS & D- and L-lactic acid derivatization by L-menthol \\
HPLC-MS & D- and L-lactic acid derivatization by & [98] \\
\hline
\end{tabular}

mentioned as organic compounds initiating development of acidosis because organic acids are formed from them by metabolism-glycolic acid, glyoxylic acid, and oxalic acid from ethylene glycol and formic acid from methanol [94-96].

Recognizing of the exact type of poison is not possible without further identification by a chemical analysis. There are suitable enzymatic assays, bioassays, and biosensors that take advantage of enzymes specific to only one isomer [33, 97-99]. An electrochemical biosensor with D-lactate dehydrogenase from archaea Candidatus caldiarchaeum subterraneum was constructed by Satomura and coworkers, and it was suitable to determine D-lactate concentration in a range 0.03-2.5 mmol/l [97]. D-Lactate oxidoreductase (cytochrome) from yeast Saccharomyces cerevisiae served for a construction of an amperometric biosensor with exerted full selectivity to D-lactate [98]. D-Lactate can be easily measured by a conventional spectral analysis when combined with recognition potency of a selective enzyme. D-Lactate dehydrogenase was chosen as a tool for measurement of D-lactate in plasma of laboratory rats [99]. In this work, the enzyme oxidized D-lactate to pyruvate with simultaneous reduction of $\mathrm{NAD}^{+}$to NADH. The created NADH provided a fluorescence signal with excitation at $340 \mathrm{~nm}$ and emission at $491 \mathrm{~nm}$.

Standard analytical instrumental methods like chromatography or mass spectrometry are not generally suitable to distinguish optical isomers; however, some improvements can be done to make them selective. Ding and coworkers derivatized the D- and L-lactic acids by L-menthol, and the following gas chromatography (GC) with mass spectrometry (MS) was suitable for their selective analysis [100]. In another work, $(S)(+)$-1-(2-pyrrolidinylmethyl)-pyrrolidine served for D- and L-lactic acid derivatization and ultraperformance liquid chromatography with mass spectrometry analyzed the product of derivatization [101]. High-performance liquid chromatography with a chiral column is another opportunity for the assay purpose. It was for instance performed by Henry and coworkers for determination of D-lactate in urine, and they combined the high-performance liquid chromatography (HPLC) with MS and employed the Astec Chirobiotic ${ }^{\mathrm{TM}} \mathrm{R}$ chiral column to achieve selectivity for the isomers [102]. A survey of analytical methods for D-lactic acid is given in Table 3.

Because the drop of $\mathrm{pH}$ is the direct consequence of $\mathrm{D}$ lactate poisoning, application of sodium bicarbonate or any other drug for acidosis-resolving purposes is recommended as first-choice therapy [103-106]. Alteration of microbiota composition like suppression of D-lactic acid-producing Lactobacillus strains by competitive probiotics is a prophylactic way leading to prevention of D-lactate exposition [50]. Standard dialysis is effective in the cases of D-lactate poisoning and can be considered at least in the cases of severe acidosis. In a case report by Anderson and coworkers, reduction of Dlactate serum level from $0.59 \mathrm{mmol} / 1$ to $0.22 \mathrm{mmol} / \mathrm{l}$ was found when continuous ambulatory peritoneal dialysis was applied overnight [107].

\section{Conclusions}

D-Lactic acid is not a highly toxic compound representing serious threats to human life. On the other hand, it is a significant marker and toxic metabolite that can cause health problems and complicate other pathologies. Poisoning cannot be easily diagnosed because elaborative analytical methods are necessary to exactly distinguish the two isomers. Unfortunately, research on the mechanism of how D-lactic acid is produced, how to prevent complications, and how to diagnose poisoning is limited. Further research in this field is necessary. Economic importance of D-lactic acid will grow because of production of biodegradable materials where $\mathrm{D}$ lactic acid is also used.

\section{Conflicts of Interest}

The author declares that they have no conflicts of interest. 


\section{Acknowledgments}

A long-term organization development plan "Medical Aspects of Weapons of Mass Destruction" and specific research funds (Faculty of Military Health Sciences, University of Defense, Czech Republic) are gratefully acknowledged.

\section{References}

[1] E. J. Lien, "Chirality and drug targeting: pros and cons," Journal of Drug Targeting, vol. 2, no. 6, pp. 527-532, 2008.

[2] Y. Yang, J. Zhang, and Y. Yao, "Enantioselective effects of chiral pesticides on their primary targets and secondary targets," Current Protein \& Peptide Science, vol. 18, no. 1, pp. 22-32, 2017.

[3] M. Zhang, G. Qing, and T. Sun, "Chiral biointerface materials," Chemical Society Reviews, vol. 41, no. 5, pp. 19721984, 2012.

[4] L. Zhang, L. Qin, X. Wang, H. Cao, and M. Liu, "Supramolecular chirality in self-assembled soft materials: regulation of chiral nanostructures and chiral functions," Advanced Materials, vol. 26, no. 40, pp. 6959-6964, 2014.

[5] L. A. Nguyen, H. He, and C. Pham-Huy, "Chiral drugs: an overview," International Journal of Biomedical Science, vol. 2, no. 2, pp. 85-100, 2006.

[6] E. Sahin, "Green synthesis of enantiopure (S)-1-(benzofuran2-yl)ethanol by whole-cell biocatalyst," Chirality, vol. 31, no. 10, pp. 892-897, 2019.

[7] T. T. Nguyen, "Traceless point-to-axial chirality exchange in the atropselective synthesis of biaryls/heterobiaryls," Organic \& Biomolecular Chemistry, vol. 17, no. 29, pp. 6952-6963, 2019.

[8] A. Gogoi, N. Mazumder, S. Konwer, H. Ranawat, N. T. Chen, and G. Y. Zhuo, "Enantiomeric recognition and separation by chiral nanoparticles," Molecules, vol. 24, no. 6, p. 1007, 2019.

[9] O. B. Evans and P. W. Stacpoole, "Prolonged hypolactatemia and increased total pyruvate dehydrogenase activity by dichloroacetate," Biochemical Pharmacology, vol. 31, no. 7, pp. 1295-1300, 1982.

[10] R. J. Merrells, A. J. Cripps, P. T. Chivers, and P. A. Fournier, "Role of lactic acidosis as a mediator of sprint-mediated nausea," Physiological Reports, vol. 7, no. 21, p. e14283, 2019.

[11] J. Theobald, J. Schneider, N. Cheema, and C. DesLauriers, "Time to development of metformin-associated lactic acidosis," Clinical Toxicology, vol. 58, no. 7, pp. 758-762, 2020.

[12] S. Romero-Garcia, H. Prado-Garcia, A. D. ValenciaCamargo, and A. Alvarez-Pulido, "Lactic acidosis promotes mitochondrial biogenesis in lung adenocarcinoma cells, supporting proliferation under normoxia or survival under hypoxia," Frontiers in Oncology, vol. 9, 2019.

[13] R. Jouffroy, P. Philippe, A. Saade, P. Carli, and B. Vivien, "Prognostic value of blood lactate and base deficit in refractory cardiac arrest cases undergoing extracorporeal life support," Turkish Journal of Anaesthesiology and Reanimation, vol. 47, no. 5, pp. 407-413, 2019.

[14] T. J. Mohammed, R. Gosain, R. Sharma, and P. Torka, "Lactic acidosis: a unique presentation of diffuse large B-cell lymphoma," BMJ Case Reports, vol. 12, no. 10, pp. e230277e230277, 2019.
[15] C. Nestor, S. Nasim, N. Coyle, and C. Canavan, "Laboratoryconfirmed metformin-associated lactic acidosis," Irish Medical Journal, vol. 112, no. 8, p. 992, 2019.

[16] H. H. Ahmed, D. De Bels, R. Attou, P. M. Honore, and S. Redant, "Elevated lactic acid during ketoacidosis: pathophysiology and management," Journal of Translational Internal Medicine, vol. 7, no. 3, pp. 115-117, 2019.

[17] J. Villar, J. H. Short, and G. Lighthall, "Lactate predicts both short- and long-term mortality in patients with and without sepsis," Infectious Diseases: Research and Treatment, vol. 12, p. 117863371986277, 2019.

[18] J. C. van der Mijn, M. J. Kuiper, C. E. H. Siegert, A. E. Wassenaar, C. J. M. van Noesel, and A. C. Ogilvie, "Lactic acidosis in prostate cancer: consider the Warburg effect," Case Reports in Oncology, vol. 10, no. 3, pp. 1085-1091, 2017.

[19] T. Sun, Y. Wu, X. Wu, and H. Ma, "Metabolomic profiles investigation on athletes' urine 35 minutes after an 800meter race," The Journal of Sports Medicine and Physical Fitness, vol. 57, no. 6, pp. 839-849, 2017.

[20] R. P. Rubin, "Carl and Gerty Cori: a collaboration that changed the face of biochemistry," Journal of Medical Biography, p. $096777201986695,2019$.

[21] S. Passarella and A. Schurr, "L-Lactate transport and metabolism in mitochondria of Hep G2 cells-the Cori cycle revisited," Frontiers in Oncology, vol. 8, 2018.

[22] K. H. Kim, B. H. Chun, J. H. Baek, S. W. Roh, S. H. Lee, and C. O. Jeon, "Genomic and metabolic features of Lactobacillus sakei as revealed by its pan-genome and the metatranscriptome of kimchi fermentation," Food Microbiology, vol. 86, p. 103341, 2020.

[23] M. Yamamoto, M. Horie, M. Fukushima, and T. Toyotome, "Culture-based analysis of fungi in leaves after the primary and secondary fermentation processes during Ishizuchikurocha production and lactate assimilation of $P$. kudriavzevii," International Journal of Food Microbiology, vol. 306, p. 108263, 2019.

[24] K. H. Kim, X. Jia, B. Jia, and C. O. Jeon, "Identification and characterization of L-malate dehydrogenases and the Llactate-biosynthetic pathway in Leuconostoc mesenteroides ATCC 8293," Journal of Agricultural and Food Chemistry, vol. 66, no. 30, pp. 8086-8093, 2018.

[25] L. Vitetta, S. Coulson, M. Thomsen, T. Nguyen, and S. Hall, "Probiotics, D-lactic acidosis, oxidative stress and strain specificity," Gut Microbes, vol. 8, no. 4, pp. 311-322, 2017.

[26] Y. Aso, A. Hashimoto, and H. Ohara, "Engineering Lactococcus lactis for D-lactic acid production from starch," Current Microbiology, vol. 76, no. 10, pp. 1186-1192, 2019.

[27] H. B. LeJohn and R. M. Stevenson, "[65] d(-)-Lactate dehydrogenases from fungi," Methods in Enzymology, vol. 41, pp. 293-298, 1975.

[28] A. Razeto, S. Kochhar, H. Hottinger, M. Dauter, K. S. Wilson, and V. S. Lamzin, "Domain Closure, Substrate Specificity and Catalysis of d-Lactate Dehydrogenase from Lactobacillus bulgaricus," Journal of Molecular Biology, vol. 318, no. 1, pp. 109-119, 2002.

[29] J. A. Lawton, N. A. Prescott, and P. X. Lawton, "From gene to structure:Lactobacillus bulgaricus D-lactate dehydrogenase from yogurt as an integrated curriculum model for undergraduate molecular biology and biochemistry laboratory courses," Biochemistry and Molecular Biology Education, vol. 46, no. 3, pp. 270-278, 2018. 
[30] N. Furukawa, A. Miyanaga, M. Togawa, M. Nakajima, and H. Taguchi, "Diverse allosteric and catalytic functions of tetrameric d-lactate dehydrogenases from three gram-negative bacteria," AMB Express, vol. 4, no. 1, pp. 76-76, 2014.

[31] M. Engqvist, M. F. Drincovich, U. I. Flugge, and V. G. Maurino, "Two D-2-hydroxy-acid dehydrogenases in Arabidopsis thaliana with catalytic capacities to participate in the last reactions of the methylglyoxal and $\beta$-oxidation pathways," The Journal of Biological Chemistry, vol. 284, no. 37, pp. 25026-25037, 2009.

[32] M. Karkovska, O. Smutok, and M. Gonchar, "Laboratory prototype of bioreactor for oxidation of toxic D-lactate using yeast cells overproducing D-lactate cytochrome c oxidoreductase," BioMed Research International, vol. 2016, 5 pages, 2016.

[33] M. Pohanka, P. Zbořil, and J. Pikula, "D-Lactate dehydrogenase (cytochrome) from Saccharomyces cerevisiae purification by fast protein liquid chromatography," Polish Journal of Chemistry, vol. 83, no. 3, pp. 415-420, 2009.

[34] G. R. Monroe, A. M. van Eerde, F. Tessadori et al., "Identification of human D lactate dehydrogenase deficiency," Nature Communications, vol. 10, no. 1, p. 1477, 2019.

[35] M. Ogata, K. Arihara, and T. Yagi, "D-Lactate dehydrogenase of Desulfovibrio vulgaris1," Journal of Biochemistry, vol. 89, no. 5, pp. 1423-1431, 1981.

[36] D. Choi, J. Kim, S. Ha et al., "Stereospecific mechanism of DJ1 glyoxalases inferred from their hemithioacetal-containing crystal structures," The FEBS Journal, vol. 281, no. 24, pp. 5447-5462, 2014.

[37] S. Jang, D. M. Kwon, K. Kwon, and C. Park, "Generation and characterization of mouse knockout for glyoxalase 1," Biochemical and Biophysical Research Communications, vol. 490, no. 2, pp. 460-465, 2017.

[38] D. H. Pfaff, T. Fleming, P. Nawroth, and A. A. Teleman, "Evidence against a role for the Parkinsonism-associated protein DJ-1 in methylglyoxal detoxification," The Journal of Biological Chemistry, vol. 292, no. 2, pp. 685-690, 2017.

[39] H. Li, Z. Tang, P. Chu et al., "Neuroprotective effect of phosphocreatine on oxidative stress and mitochondrial dysfunction induced apoptosis in vitro and in vivo: involvement of dual PI3K/Akt and Nrf2/HO-1 pathways," Free Radical Biology and Medicine, vol. 120, pp. 228-238, 2018.

[40] L. Jiang, J. Wang, Z. Wang et al., "Role of the glyoxalase system in Alzheimer's disease," Journal of Alzheimer's Disease, vol. 66, no. 3, pp. 887-899, 2018.

[41] N. Sharma, S. P. Rao, and S. V. Kalivendi, "The deglycase activity of DJ- 1 mitigates $\alpha$-synuclein glycation and aggregation in dopaminergic cells: Role of oxidative stress mediated downregulation of DJ-1 in Parkinson's disease," Free Radical Biology and Medicine, vol. 135, pp. 28-37, 2019.

[42] N. T. Moldogazieva, I. M. Mokhosoev, T. I. Mel'nikova, Y. B. Porozov, and A. A. Terentiev, "Oxidative stress and advanced lipoxidation and glycation end products (ALEs and AGEs) in aging and age-related diseases," Oxidative Medicine and Cellular Longevity, vol. 2019, Article ID 3085756, 14 pages, 2019.

[43] Ł. Łopusiewicz, E. Drozłowska, P. Siedlecka et al., "Development, characterization, and bioactivity of non-dairy kefirlike fermented beverage based on flaxseed oil cake," Food, vol. 8, no. 11, p. 544, 2019.

[44] H. M. Golder, S. E. Denman, C. McSweeney et al., "Effects of partial mixed rations and supplement amounts on milk pro- duction and composition, ruminal fermentation, bacterial communities, and ruminal acidosis," Journal of Dairy Science, vol. 97, no. 9, pp. 5763-5785, 2014.

[45] E. Haschke-Becher, O. Brunser, S. Cruchet, M. Gotteland, F. Haschke, and C. Bachmann, "Urinary D-Lactate excretion in infants receiving Lactobacillus johnsonii with formula," Annals of Nutrition and Metabolism, vol. 53, no. 3-4, pp. 240-244, 2009.

[46] D. R. Mack, "D(-)-lactic acid-producing probiotics, D(-)-lactic acidosis and infants," Canadian Journal of Gastroenterology, vol. 18, no. 11, pp. 671-675, 2004.

[47] J. Lukasik, S. Salminen, and H. Szajewska, "Rapid review shows that probiotics and fermented infant formulas do not caused-lactic acidosis in healthy children," Acta Paediatrica, vol. 107, no. 8, pp. 1322-1326, 2018.

[48] S. S. C. Rao, S. Yu, E. P. Tetangco, and Y. Yan, "Probiotics can Cause D-Lactic Acidosis and Brain Fogginess: Reply to Quigley et al.," Clinical and Translational Gastroenterology, vol. 9, no. 11, p. 207, 2018.

[49] M. Pineiro and C. Stanton, "Probiotic bacteria: legislative framework - requirements to evidence basis," The Journal of Nutrition, vol. 137, no. 3, pp. 850S-853S, 2007.

[50] B. Yilmaz, S. Schibli, A. J. Macpherson, and C. Sokollik, "D-Lactic acidosis: successful suppression of D-lactateProducingLactobacillusby probiotics," Pediatrics, vol. 142, no. 3, pp. e20180337-e20180337, 2018.

[51] C. Petersen, "D-lactic acidosis," Nutrition in Clinical Practice, vol. 20, no. 6, pp. 634-645, 2017.

[52] E. Fabian, L. Kramer, F. Siebert et al., "D-Lactic acidosis - case report and review of the literature," Zeitschrift für Gastroenterologie, vol. 55, no. 1, pp. 75-82, 2017.

[53] R. G. Ardasheva, M. D. Argirova, V. I. Turiiski, and A. D. Krustev, "Biochemical changes in experimental rat model of abdominal compartment syndrome," Folia Medica, vol. 59, no. 4, pp. 430-436, 2017.

[54] Y. S. Huang, Y. C. Li, P. Y. Tsai et al., "Accumulation of methylglyoxal andd-lactate in $\mathrm{Pb}$-induced nephrotoxicity in rats," Biomedical Chromatography, vol. 31, no. 5, 2017.

[55] P. Alarcon, A. I. Hidalgo, C. Manosalva et al., "Metabolic disturbances in synovial fluid are involved in the onset of synovitis in heifers with acute ruminal acidosis," Scientific Reports, vol. 9, no. 1, 2019.

[56] P. Naik, S. Singh, V. P. Dave, M. H. Ali, A. Kumar, and J. Joseph, "Vitreous d-lactate levels as a biomarker in the diagnosis of presumed infectious culture negative endophthalmitis," Current Eye Research, vol. 45, no. 2, pp. 184-189, 2020.

[57] M. L. Terpstra, M. Sinnige, F. Hugenholtz et al., "Butyrate production in patients with end-stage renal disease," International Journal of Nephrology and Renovascular Disease, vol. Volume 12, pp. 87-101, 2019.

[58] V. Sapin, L. Nicolet, B. Aublet-Cuvelier et al., "Rapid decrease in plasma D-lactate as an early potential predictor of diminished 28-day mortality in critically ill septic shock patients," Clinical Chemistry and Laboratory Medicine, vol. 44, no. 4, pp. 492-496, 2006.

[59] V. L. Jorgensen, N. Reiter, and A. Perner, "Luminal concentrations of L- and D-lactate in the rectum may relate to severity of disease and outcome in septic patients," Critical Care, vol. 10, no. 6, p. R163, 2006. 
[60] D. G. A. M. Bianchetti, G. S. Amelio, S. A. G. Lava et al., "DLactic acidosis in humans: systematic literature review," Pediatric Nephrology, vol. 33, no. 4, pp. 673-681, 2018.

[61] T. Takahashi, Y. Nakakita, H. Sugiyama, T. Shigyo, and K. Shinotsuka, "Classification and identification of strains of Lactobacillus brevis based on electrophoretic characterization of d-lactate dehydrogenase: Relationship between dlactate dehydrogenase and beer-spoilage ability," Journal of Bioscience and Bioengineering, vol. 88, no. 5, pp. 500-506, 1999.

[62] A. J. Geissler, J. Behr, and R. F. Vogel, "Multiple Genome Sequences of Important Beer-Spoiling Lactic Acid Bacteria: TABLE 1," Genome Announcements, vol. 4, no. 5, 2016.

[63] A. J. Geissler, J. Behr, K. von Kamp, and R. F. Vogel, "Metabolic strategies of beer spoilage lactic acid bacteria in beer," International Journal of Food Microbiology, vol. 216, pp. 60-68, 2016.

[64] K. Sakamoto and W. N. Konings, "Beer spoilage bacteria and hop resistance," International Journal of Food Microbiology, vol. 89, no. 2-3, pp. 105-124, 2003.

[65] S. Abeysekara, J. M. Naylor, A. W. A. Wassef, U. Isak, and G. A. Zello, "D-Lactic acid-induced neurotoxicity in a calf model," American Journal of Physiology-Endocrinology and Metabolism, vol. 293, no. 2, pp. E558-E565, 2007.

[66] J. W. Angell, G. L. Jones, K. Voigt, and D. H. Grove-White, "Successful correction of D-lactic acid neurotoxicity (drunken lamb syndrome) by bolus administration of oral sodium bicarbonate," Veterinary Record, vol. 173, no. 8, p. 193, 2013.

[67] S. Munakata, C. Arakawa, R. Kohira, Y. Fujita, T. Fuchigami, and H. Mugishima, "A case of D-lactic acid encephalopathy associated with use of probiotics," Brain \& Development, vol. 32, no. 8, pp. 691-694, 2010.

[68] A. D. Hingorani and N. N. Chan, "D-lactate encephalopathy," Lancet, vol. 358, no. 9295, p. 1814, 2001.

[69] M. Puwanant, L. Mo-Suwan, and S. Patrapinyokul, "Recurrent D-lactic acidosis in a child with short bowel syndrome," Asia Pacific Journal of Clinical Nutrition, vol. 14, no. 2, pp. 195-198, 2005.

[70] R. K. Narula, A. El Shafei, D. Ramaiah, and P. G. Schmitz, "d -lactic acidosis 23 years after jejuno-ileal bypass," American Journal of Kidney Diseases, vol. 36, no. 2, pp. e9.1-e9.4, 2000.

[71] R. Vidal, E. Moliner, P. P. Martin et al., "Life cycle assessment of novel aircraft interior panels made from renewable or recyclable polymers with natural fiber reinforcements and nonhalogenated flame retardants," Journal of Industrial Ecology, vol. 22, no. 1, pp. 132-144, 2018.

[72] W. Jia, R. H. Gong, C. Soutis, and P. J. Hogg, "Biodegradable fibre reinforced composites composed of polylactic acid and polybutylene succinate," Plastics, Rubber and Composites, vol. 43, no. 3, pp. 82-88, 2014.

[73] L. Mendes, A. Kangas, K. Kukko et al., "Characterization of emissions from a desktop 3D printer," Journal of Industrial Ecology, vol. 21, no. S1, pp. S94-S106, 2017.

[74] N. Hegyesi, Y. Zhang, A. Kohári, P. Polyák, X. Sui, and B. Pukánszky, "Enzymatic degradation of PLA/cellulose nanocrystal composites," Industrial Crops and Products, vol. 141, p. 111799, 2019.

[75] M. S. Singhvi, S. S. Zinjarde, and D. V. Gokhale, "Polylactic acid: synthesis and biomedical applications," Journal of Applied Microbiology, vol. 127, no. 6, pp. 1612-1626, 2019.
[76] M. Pohanka, "Three-dimensional printing in analytical chemistry: principles and applications," Analytical Letters, vol. 49, no. 18, pp. 2865-2882, 2016.

[77] A. Komesu, J. A. R. . Oliveira, L. H. . S. Martins, M. R. Wolf Maciel, and R. Maciel Filho, "Lactic acid production to purification: a review," BioResources, vol. 12, no. 2, 20174364-4383.

[78] Y. Wang, W. Deng, B. Wang et al., "Chemical synthesis of lactic acid from cellulose catalysed by lead(II) ions in water," Nature Communications, vol. 4, no. 1, 2013.

[79] E. O. Ajala, Y. O. Olonade, M. A. Ajala, and G. S. Akinpelu, "Lactic acid production from lignocellulose - a review of major challenges and selected solutions," ChemBioEng Reviews, vol. 7, no. 2, pp. 38-49, 2020.

[80] J. K. Lee, S. Kim, W. Kim et al., "Efficient production of dlactate from methane in a lactate-tolerant strain of Methylomonas sp. DH-1 generated by adaptive laboratory evolution," Biotechnology for Biofuels, vol. 12, no. 1, 2019.

[81] L. Wan, S. Zhou, and Y. Zhang, "Parallel advances in improving mechanical properties and accelerating degradation to polylactic acid," International Journal of Biological Macromolecules, vol. 125, pp. 1093-1102, 2019.

[82] Y. Robles-Bykbaev, J. Tarrío-Saavedra, S. Quintana-Pita, S. Díaz-Prado, F. J. García Sabán, and S. Naya, "Statistical degradation modelling of Poly(D,L-lactide-co-glycolide) copolymers for bioscaffold applications," PLoS One, vol. 13, no. 10, article e0204004, 2018.

[83] L. Wan and Y. Zhang, "Jointly modified mechanical properties and accelerated hydrolytic degradation of PLA by interface reinforcement of PLA-WF," Journal of the Mechanical Behavior of Biomedical Materials, vol. 88, pp. 223-230, 2018.

[84] X. Wang, J. Chen, X. Tang et al., "Biodegradation mechanism of polyesters by hydrolase from Rhodopseudomonas palustris: An in silico approach," Chemosphere, vol. 231, pp. 126-133, 2019.

[85] S. H. Lee and W. S. Song, "Enzymatic hydrolysis of polylactic acid fiber," Applied Biochemistry and Biotechnology, vol. 164, no. 1, pp. 89-102, 2011.

[86] M. Hajighasemi, B. P. Nocek, A. Tchigvintsev et al., "Biochemical and structural insights into enzymatic depolymerization of polylactic acid and other polyesters by microbial carboxylesterases," Biomacromolecules, vol. 17, no. 6, pp. 2027-2039, 2016.

[87] H. A. Lim, T. Raku, and Y. Tokiwa, "Hydrolysis of polyesters by serine proteases," Biotechnology Letters, vol. 27, no. 7, pp. 459-464, 2005.

[88] L. Zimmermann, G. Dierkes, T. A. Ternes, C. Volker, and M. Wagner, "Benchmarking the in vitro toxicity and chemical composition of plastic consumer products," Environmental Science \& Technology, vol. 53, no. 19, pp. 11467-11477, 2019.

[89] L. W. Andersen, J. Mackenhauer, J. C. Roberts, K. M. Berg, M. N. Cocchi, and M. W. Donnino, "Etiology and therapeutic approach to elevated lactate levels," Mayo Clinic Proceedings, vol. 88, no. 10, pp. 1127-1140, 2013.

[90] T. Okazaki, the Japanese Association for Acute Medicine out-of-hospital cardiac arrest (JAAM-OHCA) registry, T. Hifumi, K. Kawakita, and Y. Kuroda, "Targeted temperature management guided by the severity of hyperlactatemia for out-of-hospital cardiac arrest patients: a post hoc analysis of a nationwide, multicenter prospective registry," Annals of Intensive Care, vol. 9, no. 1, p. 127, 2019. 
[91] S. Koletzko, K. L. Waag, and B. Koletzko, "Rezidivierende D-Lactat-Acidosen mit Enzephalopathie bei einem Jungen mit Kurzdarmsyndrom," DMW - Deutsche Medizinische Wochenschrift, vol. 119, no. 13, pp. 458-462, 2008.

[92] L. T. Suárez, P. Q. Fraile, and C. P. Giner, "Dietetic treatment with fructose in a 5-year-old girl with recurrent D-lactic acidosis," Nutrición Hospitalaria, vol. 35, no. 2, pp. 495-498, 2017.

[93] L. Heireman, B. Mahieu, M. Helbert, W. Uyttenbroeck, J. Stroobants, and M. Piqueur, "High anion gap metabolic acidosis induced by cumulation of ketones, L- and D-lactate, 5-oxoproline and acute renal failure," Acta Clinica Belgica, vol. 73, no. 4, pp. 313-316, 2017.

[94] L. J. Langman, P. J. Jannetto, and M. D. Sztajnkrycer, "Unidentified anion gap metabolic acidosis," Clinical Biochemistry, vol. 65, pp. 53-54, 2019.

[95] M. Pohanka, "Antidotes against methanol poisoning: a review," Mini-Reviews in Medicinal Chemistry, vol. 19, no. 14, pp. 1126-1133, 2019.

[96] M. Pohanka, "Toxicology and the biological role of methanol and ethanol: current view," Biomedical Papers, vol. 160, no. 1, pp. 54-63, 2016.

[97] T. Satomura, J. Hayashi, H. Sakamoto et al., "d-Lactate electrochemical biosensor prepared by immobilization of thermostable dye-linked d-lactate dehydrogenase from Candidatus Caldiarchaeum subterraneum," Journal of Bioscience and Bioengineering, vol. 126, no. 4, pp. 425-430, 2018.

[98] M. Pohanka and P. Zbořil, "Amperometric biosensor for D-lactate assay," Food Technology and Biotechnology, vol. 46, no. 1, pp. 107-110, 2008.

[99] C. M. Chen, S. M. Chen, P. J. Chien, and H. Y. Yu, "Development of an enzymatic assay system of D-lactate using Dlactate dehydrogenase and a UV-LED fluorescent spectrometer," Journal of Pharmaceutical and Biomedical Analysis, vol. 116, pp. 150-155, 2015.

[100] X. Ding, S. Lin, H. Weng, and J. Liang, "Separation and determination of the enantiomers of lactic acid and 2hydroxyglutaric acid by chiral derivatization combined with gas chromatography and mass spectrometry," Journal of Separation Science, vol. 41, no. 12, pp. 2576-2584, 2018.

[101] H. Tsutsui, T. Mochizuki, T. Maeda et al., "Simultaneous determination of DL-lactic acid and DL-3-hydroxybutyric acid enantiomers in saliva of diabetes mellitus patients by high-throughput LC-ESI-MS/MS," Analytical and Bioanalytical Chemistry, vol. 404, no. 6-7, pp. 1925-1934, 2012.

[102] H. Henry, N. Marmy Conus, P. Steenhout, A. Béguin, and O. Boulat, "Sensitive determination of D-lactic acid and L-lactic acid in urine by high-performance liquid chromatography-tandem mass spectrometry," Biomedical Chromatography, vol. 26, no. 4, pp. 425-428, 2012.

[103] D. K. Zimmermann, R. Weisser, and R. Mansfeld, "Treatment of systemic acidosis in calves by administration of sodium bicarbonate with stomach tube," Tieraerztliche Praxis Ausgabe Grosstiere Nutztiere, vol. 36, no. 3, pp. 155-162, 2008.

[104] J. K. Suagee-Bedore, A. L. Wagner, and I. D. Girard, "Feeding DigestaWell Buffer to Horses Alters the Effects of Starch Intake on Blood $\mathrm{pH}$, Lipopolysaccharide, and Interleukin$1 \beta$," Journal of Equine Veterinary Science, vol. 61, pp. 3645,2018 .
[105] F. M. Trefz, P. D. Constable, and I. Lorenz, "Effect of intravenous small-volume hypertonic sodium bicarbonate, sodium chloride, and glucose solutions in decreasing plasma potassium concentration in hyperkalemic neonatal calves with diarrhea," Journal of Veterinary Internal Medicine, vol. 31, no. 3, pp. 907-921, 2017.

[106] F. M. Trefz, A. Lorch, M. Feist, C. Sauter-Louis, and I. Lorenz, "Construction and validation of a decision tree for treating metabolic acidosis in calves with neonatal diarrhea," BMC Veterinary Research, vol. 8, no. 1, p. 238, 2012.

[107] Y. Anderson, N. Curtis, J. Hobbs et al., "High serum D-lactate in patients on continuous ambulatory peritoneal dialysis," Nephrology Dialysis Transplantation, vol. 12, no. 5, pp. 981983, 1997. 